\title{
超高強度コンクリート用微粉末のモルタルによる 活性度指数試験結果の再現性に関する一考察 \\ CONSIDERATION IN REPEATABILITY OF ACTIVITY INDEX TEST RESULTS OF MICRO POWDER FOR ULTRA-HIGH STRENGTH CONCRETE BASED ON MORTAR
}

陣内浩*1

Hiroshi JINNAI

\begin{abstract}
This paper describes with experimental study on repeatability of activity index test results of micro powder for ultra-high strength concrete based on mortar. This investigation led to the following conclusions. 1) It is possible to obtain a compressive strength test result of the standard mortar with repeatability by a present test method when used material is same. As a result, the repeatability of a result of the activity index test can also be secured. 2) To change the kind of chemical admixture has a high possibility which influences the repeatability of a result of the activity index test.
\end{abstract}

Keywords : Activity index, Repeatability, Standard mortar, Flow, Mixing time, Chemical admixture 活性度指数, 再現性, 基淮モルタル, フロー, 練混せ時間, 化学混和剤

\section{1. はじめに}

コンクリート用混和材の活性度指数試験は，セメントに対する各 種混和材の代替性能を評価する試験として，JIS A 6201 （コンクリ ート用フライアッシュ), JIS A 6206 (コンクリート用高炉スラグ微 粉末), JIS A 6207 (コンクリート用シリカフューム) などに規定さ れている。国内の歴史としては, JIS A 6201 が 1958 年の制定時に 定めた圧縮強度比の考え方を改良したものであり, 同 JIS では 1996 年の改正時から現行の活性度指数試験方法となっている 11 。

2000 年に制定された JIS A 6207 でも，すでに普及していた日本 建築学会「シリカフュームを用いたコンクリートの調合設計・施工ガ イドライン」 ${ }^{2}$ および土木学会「シリカフュームを用いたコンクリー トの設計・施工指針（案）」3)の考え方を踏襲し，コンクリート用フ ライアッシュと同様の活性度指数試験方法が規定された。しかしな がら, 低水結合材比の領域で使用されることの多いシリカフューム の活性度指数を評価するには, JIS A 6201 で規定している水結合材 比 $50 \%$ のモルタルは適当ではないという実験結果 4 )から，2011 年 版の JIS A 6207 より試験に用いるモルタルの水結合材比が 30\%に 改正された。この改正から 10 年弱が経過し, 改正点に関連する問 題はあまり議論されることがなかったが, 2020 年に制定された JIS A 6209 (コンクリート用火山ガラス微粉末) の原案作成作業中に行 った JIS A 6207 の活性度指数試験方法を引用した共通実験で, 試験 結果の再現性が確保できないケースが指摘された 5),6)。そこで，JIS A 6207 に規定する活性度指数試験方法の試験結果の再現性に関す
る実験的な検証を行うこととした。

\section{2. 対象とする活性度指数試験方法}

本研究が対象とする活性度指数試験方法は, JIS A 6207 附属書 C (コンクリート用シリカフュームのモルタルによる活性度指数の試 験方法）とした。本試験方法は，普通ポルトランドセメントのみで 練り混ぜたモルタル（基準モルタル）の圧縮強度と, 普通ポルトラ ンドセメントの $10 \%$ をシリカフュームに置き換えた結合材で練り 混ぜたモルタル（試験モルタル）の圧縮強度を式（1）に代入し， 材齢 7 日および材齢 28 日での活性度指数を求めることとなってい る。一部の規定を変更しているが，本試験は JIS A 6209 にも引用さ れている。使用する普通ポルトランドセメントは 3 種類のものを同 量で混合するように規定されており，使用するセメントの物性值の 変動が試験結果に及ぼす影響を抑制するようになっている。また， 使用する細骨材は，JIS R 5201 （セメントの物理試験方法）で定め ている標準砂を使用することとなっている。基準モルタルおよび試 験モルタルの水結合材比は $30 \%$ と定められており, 練り上げたモル タルの空気量は $2.0 \%$ 以下とするように規定されている。

$$
\begin{aligned}
& A_{S}=C_{1} / C_{2} \times 100 \\
& \text { ここに, } A_{S}: \text { 活性度指数 }(\%) \\
& C_{1} \text { : 各材齢における試験モルタルの圧縮強度 } \\
& C_{2} \text { : 各材齢における基準モルタルの圧縮強度 }
\end{aligned}
$$

\footnotetext{
*1 東京工芸大学工学部建築学科 教授 ·博士 (工学) Prof., Dept. of Architecture, Faculty of Engineering, Tokyo Polytechnic University, Ph.D
} 


\section{3. 基準モルタルの試験結果の再現性}

試験結果の再現性を検討するにあたり，まずは活性度指数の評価 の基準となる基準モルタルの試験結果の再現性を確認することと した。JIS に示される基準モルタルの調合を Table1 に示寸。実務的 な観点から, 基準モルタルの計量值は, セメント協会が販売してい るセメント強さ試験用標準砂の一袋分の細骨材（1350g）を使用す ることを前提に定められている。また, 砂セメント比は, すでに普 及していた日本建築学会「高強度コンクリート施工指針(案)」に示さ れる JASS 5T-701-2005（高強度コンクリート用セメントの品質基 準(案)） 7) と同様の 1.4 としている。この計量值でモルタルを練り混 ぜると，概ね 1 リットルのモルタルを練り上げることができるが， 圧縮強度試験に用いる $\Phi 50 \times 100 \mathrm{~mm}$ の供試体を 6 個作製するには 不足するため, 試験にあたっては 2 バッチのモルタルが必要になる。 つまり, 1 回の活性度指数試験では, 異なるバッチのモルタルを同 じ性能のモルタルとして扱うため, 試験結果の再現性は極めて重要 となる。そこで, ここでは基準モルタルを連続 12 バッチ練り混ぜ, フレッシュモルタルおよび硬化モルタルの試験結果の再現性を確 認した。

モルタルの練混ぜは $20 \pm 3{ }^{\circ} \mathrm{C} の$ 実験室で行った。実験開始時の実 験室内の湿度は $60 \%$ であった。使用材料を Table2 に示す。練混ぜ 水も含め, 使用する材料はすべて前述の実験室内 $\left(20 \pm 3^{\circ} \mathrm{C}\right)$ で保 管したものを使用した。使用するセメントは，同じセメント袋のも のをビニル袋に小分けして計量したものを使用した。標準砂は, 15 箱入りの同じロットNo.のものから 12 袋を使用した。化学混和剂に はポリカルボン酸系高性能 $\mathrm{AE}$ 減水剂を使用し, 消泡剂にはポリア ルキレングリコール誘導体系消泡剂を使用した。両混和剤の使用量 は, 予備試験の結果を参考に 1 バッチ目の使用量を定め, 練上がっ た 1 バッチ目のモルタルのフローおよび空気量が, JIS A 6207 附属 書 $\mathrm{C}$ に示される $260 \pm 10 \mathrm{~mm}$ および $2.0 \%$ 以下となることを確認し て設定した。各混和剤の使用量は, 全バッチ共通の量として, 高性 能 $\mathrm{AE}$ 減水剤はセメント質量の $2.0 \%$, 消泡剤はセメント質量の $0.3 \%$ とている。

\section{1 フレッシュモルタルにおける試験結果の再現性}

12 バッチのモルタルの練上がり時のフローを Fig. 1 に示す。平均 值は $253 \mathrm{~mm}$, 変動係数は $2.5 \%$ であった。前述のように条件を揃え て練り混ぜても, ある程度のばらつきのある結果となった。全体像 としては，5 バッチ目がやや特異な結果で, それ以外は平均值士 $10 \mathrm{~mm}$ 内に分布した。平均值がやや低めであるため, $1 / 3$ の結果が

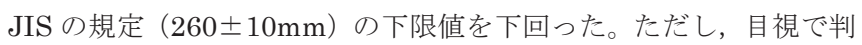
断する限り, 各モルタルの流動性にはあまり差がなく, フローの值 がやや小さいモルタルであっても, 供試体の打込みに支障が生じる ものではなかった。12 バッチのモルタルの練上がり時の空気量を Fig. 2 に示寸。平均值は $1.6 \%$, 変動係数は $12.5 \%$ であった。変動係 数で見ると数值が大きく見えるが, 各バッチの試験結果は平均值士 $0.4 \%$ に分布した比較的安定したものであった。空気量に関しては, 全バッチが JIS の規定である $2.0 \%$ 以下を満足した。

\section{2 硬化モルタルにおける試験結果の再現性}

12 バッチのモルタルの供試体の採取方法を Fig. 3 に示す。硬化モ ルタルの圧縮強度の試験では, JIS A 6207 の活性度指数試験に規定 される $\Phi 50 \times 100 \mathrm{~mm}$ の円柱供試体および JIS A 6201 の水結合材比
Table1 Mix proportion of standard mortar

\begin{tabular}{c|c|c|c}
\hline Cement* & Test sample & Standard sand & $\begin{array}{c}\text { Total amount of } \\
\text { water and } \\
\text { admixture }\end{array}$ \\
\hline \hline $964 \pm 2 \mathrm{~g}$ & 0 & $1350 \pm 5 \mathrm{~g}$ & $289 \pm 1 \mathrm{~g}$ \\
\hline
\end{tabular}

*Mixing equivalent amount of three different Ordinary portland cement

Table2 Materials

\begin{tabular}{|c|c|}
\hline $\begin{array}{l}\text { Ordinary } \\
\text { portland } \\
\text { cementA }\end{array}$ & $\begin{array}{l}\text { Density: } 3.16 \mathrm{~g} / \mathrm{cm}^{3} \\
\text { Specific surface area: } 3,250 \mathrm{~cm}^{2} / \mathrm{g}\end{array}$ \\
\hline $\begin{array}{l}\text { Ordinary } \\
\text { portland } \\
\text { cementB }\end{array}$ & $\begin{array}{l}\text { Density: } 3.16 \mathrm{~g} / \mathrm{cm}^{3} \\
\text { Specific surface area: } 3,350 \mathrm{~cm}^{2} / \mathrm{g}\end{array}$ \\
\hline $\begin{array}{l}\text { Ordinary } \\
\text { portland } \\
\text { cementC }\end{array}$ & $\begin{array}{l}\text { Density: } 3.15 \mathrm{~g} / \mathrm{cm}^{3} \\
\text { Specific surface area: } 3,280 \mathrm{~cm}^{2} / \mathrm{g}\end{array}$ \\
\hline $\begin{array}{l}\text { Standard } \\
\text { sand }\end{array}$ & $\begin{array}{l}\text { Density in saturated surface-dry condition: } 2.65 \mathrm{~g} / \mathrm{cm}^{3} \\
\text { Water absorption: } 0.42 \%\end{array}$ \\
\hline Water & Tap water \\
\hline $\begin{array}{l}\text { Chemical } \\
\text { admixture }\end{array}$ & $\begin{array}{l}\text { Air-entraining and high-range water-reducing } \\
\text { admixture }\end{array}$ \\
\hline
\end{tabular}

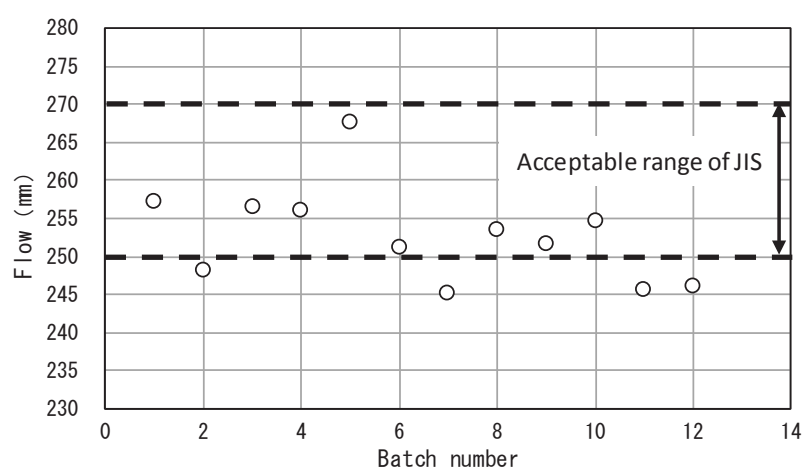

Fig. 1 Test results of mortar flow

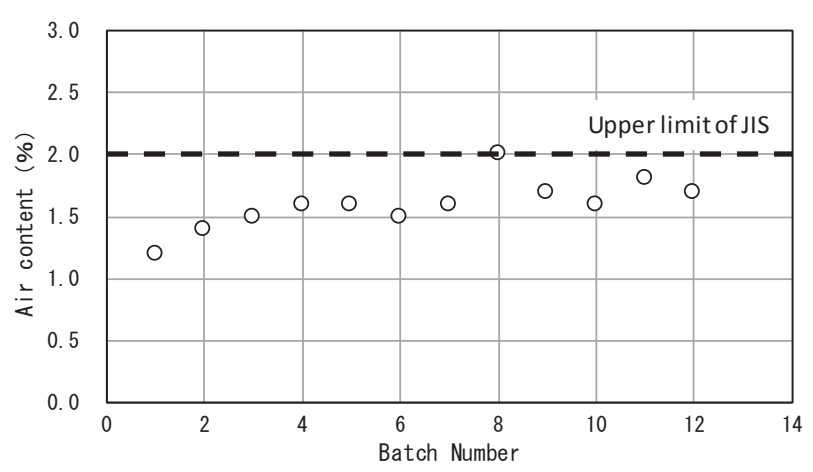

Fig. 2 Test results of air content

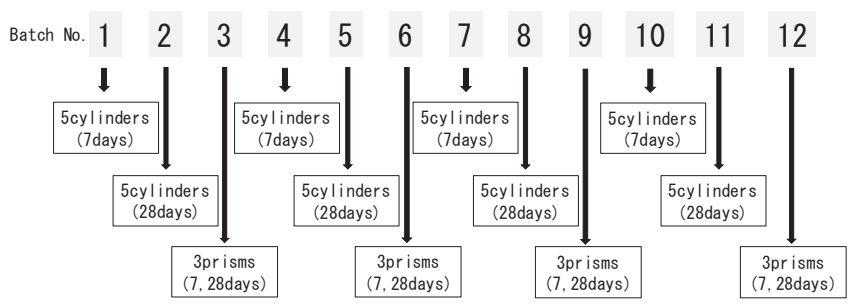

Fig. 3 Sampling method of specimens 
Table3 Compressive strength test results of standard mortar

\begin{tabular}{|c|c|c|c|c|c|c|c|c|c|c|c|c|c|}
\hline \multicolumn{8}{|c|}{ Cylinder $(\Phi 50 \times 100 \mathrm{~mm})$} & \multicolumn{6}{|c|}{$\operatorname{Prism}(40 \times 40 \times 160 \mathrm{~mm})$} \\
\hline \multicolumn{4}{|c|}{ 7days } & \multicolumn{4}{|c|}{ 28days } & \multicolumn{3}{|c|}{ 7days } & \multicolumn{3}{|c|}{\begin{tabular}{|c|} 
28days \\
\end{tabular}} \\
\hline $\begin{array}{c}\text { Batch } \\
\text { No. }\end{array}$ & $\begin{array}{c}\text { Specimen } \\
\text { No. }\end{array}$ & $\begin{array}{c}\text { Density } \\
\left(\mathrm{g} / \mathrm{cm}^{3}\right)\end{array}$ & \begin{tabular}{|c|}
$\begin{array}{c}\text { Compressive } \\
\text { Strength } \\
(\mathrm{MPa})\end{array}$ \\
\end{tabular} & \begin{tabular}{|c|}
$\begin{array}{c}\text { Batch } \\
\text { No. }\end{array}$ \\
\end{tabular} & $\begin{array}{c}\text { Specimen } \\
\text { No. }\end{array}$ & $\begin{array}{c}\text { Density } \\
\left(\mathrm{g} / \mathrm{cm}^{3}\right)\end{array}$ & $\begin{array}{c}\text { Compressive } \\
\text { Strength } \\
(\mathrm{MPa})\end{array}$ & $\begin{array}{l}\text { Batch } \\
\text { No. }\end{array}$ & \begin{tabular}{|c|}
$\begin{array}{c}\text { Specimen } \\
\text { No. }\end{array}$ \\
\end{tabular} & \begin{tabular}{|c}
$\begin{array}{c}\text { Compressive } \\
\text { Strength } \\
(\mathrm{MPa})\end{array}$ \\
\end{tabular} & $\begin{array}{c}\text { Batch } \\
\text { No. }\end{array}$ & $\begin{array}{c}\text { Specimen } \\
\text { No. }\end{array}$ & $\begin{array}{c}\text { Compressive } \\
\text { Strength } \\
(\mathrm{MPa}) \\
\end{array}$ \\
\hline \multirow{7}{*}{1} & 1 & 2.348 & 94.6 & \multirow{7}{*}{2} & 1 & 2.377 & 118 & \multirow{7}{*}{3} & 1 & 96.9 & \multirow{7}{*}{3} & 1 & 98.3 \\
\hline & 2 & 2.347 & 94.7 & & 2 & 2.355 & 113 & & 2 & 98.5 & & 2 & 101 \\
\hline & 3 & 2.354 & 97.1 & & 3 & 2.363 & 114 & & 3 & 98.8 & & 3 & 109 \\
\hline & 4 & 2.365 & 97.4 & & 4 & 2.355 & 111 & & & & & & \\
\hline & 5 & 2.360 & 99.2 & & 5 & 2.375 & 118 & & & & & & \\
\hline & Ave. & 2.355 & 96.6 & & Ave. & 2.365 & 115 & & Ave. & 98.1 & & Ave. & 103 \\
\hline & $\mathrm{V}(\%)$ & 0.3 & 2.0 & & $\mathrm{~V}(\%)$ & 0.4 & 2.7 & & $\mathrm{~V}(\%)$ & 1.0 & & $\mathrm{~V}(\%)$ & 5.4 \\
\hline \multirow{7}{*}{4} & 1 & 2.347 & 96.1 & \multirow{7}{*}{5} & 1 & 2.364 & 113 & \multirow{7}{*}{6} & 1 & 84.8 & \multirow{7}{*}{6} & 1 & 103 \\
\hline & 2 & 2.355 & 96.6 & & 2 & 2.362 & 114 & & 2 & 102 & & 2 & 107 \\
\hline & 3 & 2.345 & 94.0 & & 3 & 2.360 & 114 & & 3 & 97.4 & & 3 & 112 \\
\hline & 4 & 2.361 & 97.4 & & 4 & 2.371 & 116 & & & & & & \\
\hline & 5 & 2.366 & 99.9 & & 5 & 2.371 & 118 & & & & & & \\
\hline & Ave. & 2.355 & 96.8 & & Ave. & 2.366 & 115 & & Ave. & 94.7 & & Ave. & 107 \\
\hline & $\mathrm{V}(\%)$ & 0.4 & 2.2 & & $\mathrm{~V}(\%)$ & 0.2 & 1.7 & & $\mathrm{~V}(\%)$ & 9.4 & & $\mathrm{~V}(\%)$ & 4.2 \\
\hline \multirow{7}{*}{7} & 1 & 2.348 & 95.5 & \multirow{7}{*}{8} & 1 & 2.362 & 114 & \multirow{7}{*}{9} & 1 & 93.1 & \multirow{7}{*}{9} & 1 & 106 \\
\hline & 2 & 2.343 & 96.5 & & 2 & 2.367 & 116 & & 2 & 91.9 & & 2 & 111 \\
\hline & 3 & 2.359 & 97.1 & & 3 & 2.357 & 114 & & 3 & 91.9 & & 3 & 108 \\
\hline & 4 & 2.360 & 95.8 & & 4 & 2.362 & 111 & & & & & & \\
\hline & 5 & 2.360 & 99.4 & & 5 & 2.361 & 115 & & & & & & \\
\hline & Ave. & 2.354 & 96.9 & & Ave. & 2.362 & 114 & & Ave. & $\begin{array}{l}92.7 \\
\end{array}$ & & Ave. & 108 \\
\hline & $\mathrm{V}(\%)$ & 0.3 & 1.6 & & $\mathrm{~V}(\%)$ & 0.2 & 1.6 & & $\mathrm{~V}(\%)$ & 0.7 & & $\mathrm{~V}(\%)$ & 2.32 \\
\hline \multirow{7}{*}{10} & 1 & 2.348 & 96.5 & \multirow{7}{*}{11} & 1 & 2.356 & 111 & \multirow{7}{*}{12} & 1 & 91.9 & \multirow{7}{*}{12} & 1 & 105 \\
\hline & 2 & 2.343 & 96.0 & & 2 & 2.363 & 117 & & 2 & 92.1 & & 2 & 108 \\
\hline & 3 & 2.362 & 97.6 & & 3 & 2.354 & 113 & & 3 & 91.5 & & 3 & 111 \\
\hline & 4 & 2.358 & 99.8 & & 4 & 2.355 & 115 & & & & & & \\
\hline & 5 & 2.355 & 98.3 & & 5 & 2.367 & 117 & & & & & & \\
\hline & Ave. & 2.353 & 97.6 & & Ave. & 2.359 & 115 & & Ave. & 91.8 & & Ave. & 108 \\
\hline & $\mathrm{V}(\%)$ & 0.3 & 1.5 & & $\mathrm{~V}(\%)$ & 0.2 & 2.3 & & $\mathrm{~V}(\%)$ & 0.3 & & $\begin{array}{l}\mathrm{V}(\%) \\
\end{array}$ & 2.8 \\
\hline \multicolumn{2}{|c|}{$\begin{array}{c}\text { Ave. of } \\
20 \text { specimens }\end{array}$} & 2.354 & 97.0 & \multicolumn{2}{|c|}{$\begin{array}{c}\text { Ave. of } \\
20 \text { specimens }\end{array}$} & 2.363 & 115 & \multicolumn{2}{|c|}{$\begin{array}{c}\text { Ave. of } \\
12 \text { specimens }\end{array}$} & 94.3 & \multicolumn{2}{|c|}{$\begin{array}{c}\text { Ave. of } \\
12 \text { specimens }\end{array}$} & 107 \\
\hline $\begin{array}{r}\mathrm{V} \\
\text { speci }\end{array}$ & imens $(\%)$ & 0.3 & 1.8 & $\begin{array}{r}\mathrm{V} \\
\text { speci }\end{array}$ & of 200 & 0.3 & 2.0 & $\begin{array}{r}\mathrm{V} \\
\text { speci }\end{array}$ & imens $12 \%$ & 4.9 & $\begin{array}{r}\mathrm{V} \\
\text { spec }\end{array}$ & $\begin{array}{l}\text { of } 12 \\
\text { imens }(\%)\end{array}$ & 3.9 \\
\hline
\end{tabular}

$\mathrm{V}$ : variation coefficient

$50 \%$ のモルタルを用いた活性度指数試験で使用されている $40 \times 40$ $\times 160 \mathrm{~mm}$ の角柱供試体を使用した。それぞれの供試体は, Fig.3に 示寸バッチから採取した。より多くの試験結果を得るため， $\Phi 50 \times$ $100 \mathrm{~mm}$ の円柱供試体については，1 バッチから採取可能な 5 個の 供試体を採取した。 $40 \times 40 \times 160 \mathrm{~mm}$ の角柱供試体については 1 バ ッチから採取可能な 3 個の供試体を採取し, 試験日当日に各供試体 をJIS R 5201「11.2.5 曲げ強さ試験機」に示される三点曲げ試験の 要領で二分割した 6 個の供試体で圧縮強度試験を行った。また, 角 柱供試体の圧縮強度試験は JIS R 5201「11.6 測定」, 圧縮強度の算定 方法は JIS R 5201「11.7 計算」によって行うこととした。なお, 角柱 供試体の作り方は JIS R 5201「11.5.3 成形」に準じて行っているが, モルタル自体が JIS R 5201 で扱うモルタルよりも流動性が高いこ と, また円柱供試体との比較試験であることを考慮し, テーブルバ イブレータを用いた詰め方は採用しなかった。この代替案として, 今回の実験での角柱供試体は, モルタルを 2 層に別けて詰め, それ ぞれ JIS R 5201-1992 に規定されていた 35mm 角の突き棒で全面 にわたって 5 回ずつ突き, その後, 型枠を少し傾け, 床に落とすよ うにして軽く振動を与えて空気を追い出す方法で成形することとし た。

材齢 7 日および材齢 28 日に行った圧縮強度試験結果を Table 3 に 示す。後述するデータ整理の結果などを踏まえ, 供試体の密度は測 定值から計算した值を小数点以下 3 桁まで示している。 $\Phi 50 \times 100$
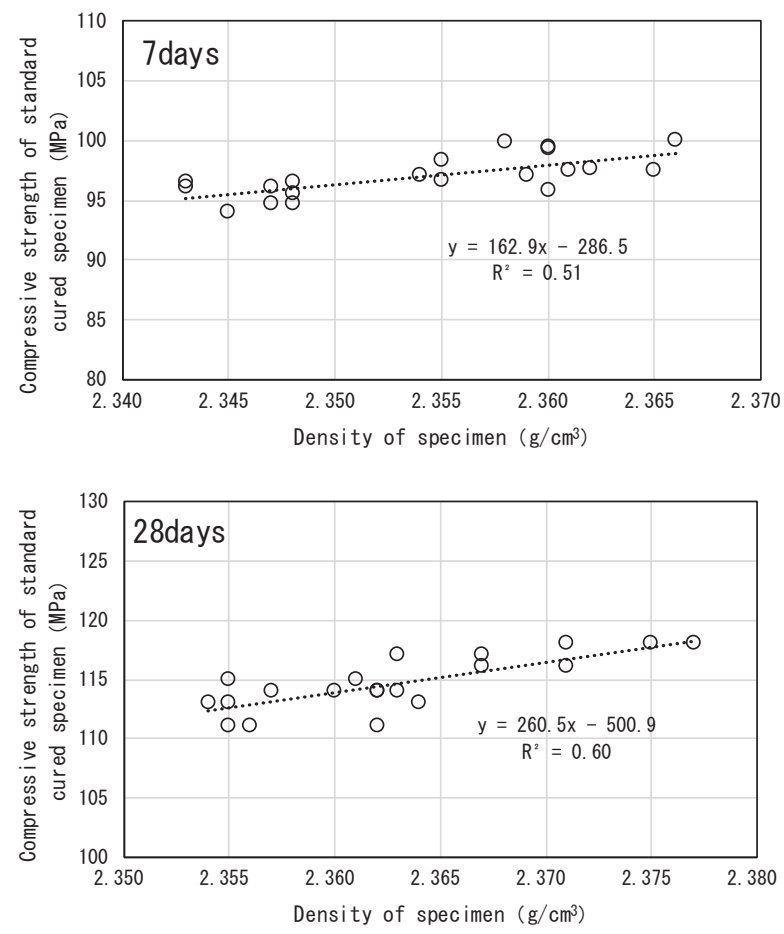

Fig. 4 Relation between density of specimen and compressive strength of cylinder specimen 
$\mathrm{mm}$ の円柱供試体を用いた試験では, 材齢 7 日, 材齢 28 日ともに, バッチ内およびバッチ間での供試体密度や圧縮強度の変動は小さか った。4 バッチの合計 20 個の供試体の圧縮強度の変動係数で見ても, $2 \%$ 以下の安定した試験結果が得られた。この結果から考えれば, 現行 JIS に従って実施した基準モルタルの圧縮強度試験では, 十分 に再現性のある結果が得られるものと考える。一方， $40 \times 40 \times$ $160 \mathrm{~mm}$ の角柱供試体を用いた試験では, 前述した円柱供試体を用 いた試験結果よりもやや低い圧縮強度となり, バッチ内およびバッ チ間での圧縮強度の変動もやや大きくなった。現行 JIS では, 圧縮 強度 $100 \mathrm{~N} / \mathrm{mm}^{2}$ 程度のモルタルの圧縮強度試験では, 研磨による載 荷面の整形が難しい角柱供試体の使用は不向きという理由などから, 上下面を研磨処理した $\Phi 50 \times 100 \mathrm{~mm}$ の円柱供試体での試験を規定 している。今回の試験でも, 角柱供試体の使用はあまり推奨できな い結果となった。

$\Phi 50 \times 100 \mathrm{~mm}$ 供試体の圧縮強度を, 各供試体の密度で整理した ものを Fig.4 に示寸。使用材料や練混ぜ方法を揃えているとはいえ, 各供試体の密度をまったく同じとすることはできない。Fig.4 に示 すように, 供試体の密度と圧縮強度には明確な相関があり, 現行の JIS 通りに試験を行っても, 供試体の成形に起因する試験誤差が, 活性度指数試験の結果にある程度影響すると考えてよい。この点に ついては, 今後の課題と考える。

以上の結果を整理すると，使用材料が同じであれば，現行の JIS の方法で再現性のある基準モルタルの圧縮強度試験結果を得ること ができることが確認できた。また，この試験結果には，供試体の密 度差によって圧縮強度が変動する影響が含まれることも確認された。 さらに, 今回の試験では, モルタルのフローの值が現行の JIS の規 定の範囲になくても, 再現性のある試験結果が得られる可能性を示 唆していた。

\section{4. フロー值の変化が活性度指数試験結果の再現性に及ぼす影響}

現行の JIS A 6207 の活性度指数試験の規定では, モルタルのフロ 一の值は $260 \pm 10 \mathrm{~mm}$ となっている。しかしながら, 前章 3 .の結果 は, 同じ材料で繰り返し試験を行ってもフローの值が規定の範囲に 収まらないことがあることを示すとともに，その下限值を下回って も圧縮強度にはあまり影響しないことを示していた。そこで，シリ カフュームと火山ガラス微粉末を試験サンプルとして, フローの值 の変化が活性度指数試験結果の再現性に及ぼす影響について検討す ることとした。

使用した超高強度コンクリート用微粉末を Table4 に示す。シリ カフュームは, 実際に超高強度コンクリートの製造に利用されてい るシリカフューム A と, 比較的強熱減量の值が高く, 化学混和剤を 吸着しやすいシリカフューム B を使用した。いずれも比表面積や成 分は JIS A 6207 の規格品に相当する。火山ガラス微粉末も, 比表面 積や成分が JIS A 6209 の I 種に相当するものを使用した。微粉末以 外の使用材料は, すべて前章 3 .と同じときに受け入れたものである。

実験の要因と水準を Table5 に示す。結合材の種類は，基準モル タルとなる普通ポルトランドセメントのみとしたもの 1 種, 試験モ ルタルとなる普通ポルトランドセメントの $10 \%$ table4 に示した 3 つの超高強度コンクリート用微粉末に置換したもの 3 種とした。 化学混和剂は, 高性能 $\mathrm{AE}$ 減水剂および超高強度コンクリート用の
Table4 Micro powders

\begin{tabular}{|c|c|c|c|c|}
\hline & & Silica fume A & Silica fume B & $\begin{array}{l}\text { Volcanic glass } \\
\text { powder }\end{array}$ \\
\hline \multicolumn{2}{|c|}{$\begin{array}{c}\text { Specific surface area } \\
\left(\mathrm{m}^{2} / \mathrm{g}\right)\end{array}$} & 19.3 & 23.2 & 10.4 \\
\hline \multicolumn{2}{|c|}{ Density $\left(\mathrm{g} / \mathrm{cm}^{3}\right)$} & 2.26 & 2.39 & 2.37 \\
\hline \multicolumn{2}{|c|}{$\mathrm{SiO}_{2}(\%)$} & 92.7 & 96.9 & 72.9 \\
\hline \multicolumn{2}{|c|}{$\mathrm{MgO}(\%)$} & 0.58 & 0.40 & 0.31 \\
\hline \multicolumn{2}{|c|}{$\mathrm{C}_{3} \mathrm{~S}(\%)$} & 0.24 & 0.28 & - \\
\hline \multicolumn{2}{|c|}{ Chloride ion (\%) } & 0.06 & 0.06 & - \\
\hline \multicolumn{2}{|c|}{$\mathrm{Al}_{2} \mathrm{O}_{3}(\%)$} & - & - & 13.0 \\
\hline \multicolumn{2}{|c|}{$\mathrm{Fe}_{2} \mathrm{O}_{2}(\%)$} & - & - & 2.22 \\
\hline \multicolumn{2}{|c|}{$\mathrm{Na}_{2} \mathrm{O}(\%)$} & - & - & 3.45 \\
\hline \multicolumn{2}{|c|}{$\mathrm{K}_{2} \mathrm{O}(\%)$} & - & - & 3.39 \\
\hline \multicolumn{2}{|c|}{ Ignition loss (\%) } & 1.90 & 2.51 & 2.99 \\
\hline \multicolumn{2}{|c|}{ Humidity (\%) } & 0.19 & 0.80 & 0.67 \\
\hline \multirow{2}{*}{$\begin{array}{c}\text { Activity } \\
\text { index } \\
(\%)\end{array}$} & 7 days & 102 & - & - \\
\hline & 28 days & 115 & - & - \\
\hline
\end{tabular}

Table5 Parameters

\begin{tabular}{l|l|l}
\hline \multicolumn{1}{c|}{ Binders } & \multicolumn{1}{c}{ Chemical admixtures } & \multicolumn{1}{c}{ Flows } \\
\hline \hline 1) $\mathrm{O}=100$ & & 1) $260 \pm 10 \mathrm{~mm}$ \\
2) $\mathrm{O}: \mathrm{SA}=90: 10$ & 1) $\mathrm{SP}$ & 2) $230 \pm 10 \mathrm{~mm}$ \\
3) $\mathrm{O}: \mathrm{SB}=90: 10$ & 2) HSP & 3) $200 \pm 10 \mathrm{~mm}$ \\
4) $\mathrm{O}: \mathrm{V}=90: 10$ & & \\
\hline $\mathrm{O}:$ Ordinary portland cement, SA : Silica fume A \\
$\mathrm{SB}:$ Silica fume B, V : Volcanic glass powder \\
$\mathrm{SP}:$ Air-entraining and high-range water-reducing admixture \\
HSP : high-range water-reducing admixture (for ultra-high strength \\
concrete)
\end{tabular}

高性能減水剤の 2 種とした。目標とするモルタルのフローは, JIS の規定通りである $260 \pm 10 \mathrm{~mm}$ と，それよりも小さな $230 \pm 10 \mathrm{~mm}$ および $200 \pm 10 \mathrm{~mm}$ の 3 種とした。

モルタルの練混ぜは $20 \pm 3^{\circ} \mathrm{C} の$ 実験室で行った。実験開始時の実 験室内の湿度は $51 \%$ であった。試験日の室内の湿度はやや低かった が，1 バッチの試験時間は比較的短いため, 試験值への影響はほぼ 無視できると判断した。フレッシュモルタルおよび硬化モルタルの 試験結果を Table6 に示す。前章と同様に，消泡剤にはポリアルキ レングリコール誘導体系消泡剂を使用し，化学混和剤の種類にかか わらず，使用量は全バッチともセメント質量の $0.3 \%$ とした。表に 示した各モルタルの調合名は，次のルールで定めている。

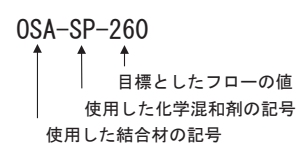

シリカフューム Aおよび火山ガラス微粉末を用いたモルタルは問 題なく練り混ぜることができた。一方, 強熱減量の多いシリカフュ 一ム B を用いたモルタルは化学混和剤の使用量が明らかに多く, 高 性能 $\mathrm{AE}$ 減水剤を使用したケースでは，化学混和剤の使用量を結合 材の質量の $4.0 \%$ としても, フロー $200 \mathrm{~mm}$ 程度のモルタルを練り上 げることしかできなかった。引き続き，結合材の質量の $5.0 \%$ お び 6.0\%の高性能 $\mathrm{AE}$ 減水剂を使用したバッチも練り混ぜたが，フ ローの值はそれぞれ $211 \times 209 \mathrm{~mm} ， 212 \times 209 \mathrm{~mm}$ にしかならなか ったため, 目標フロー $260 \pm 10 \mathrm{~mm}$ および $230 \pm 10 \mathrm{~mm}$ のモルタル の作製は諦めた。今回の試験で使用しているシリカフューム B の強 
Table6 Activity index test results

\begin{tabular}{|c|c|c|c|c|c|c|c|c|c|}
\hline & \multirow{2}{*}{$\begin{array}{l}\text { Dosage of } \\
\text { chemical } \\
\text { Admixture } \\
(\%)\end{array}$} & \multirow[b]{2}{*}{$\begin{array}{l}\text { Flow } \\
(\mathrm{mm})\end{array}$} & \multirow[b]{2}{*}{$\begin{array}{c}\text { Temperature } \\
\left({ }^{\circ} \mathrm{C}\right)\end{array}$} & \multirow[b]{2}{*}{$\begin{array}{c}\text { Air } \\
\text { content } \\
(\%)\end{array}$} & \multirow{2}{*}{$\begin{array}{l}\text { Density } \\
\text { of flesh } \\
\text { mortar } \\
\left(\mathrm{g} / \mathrm{cm}^{3}\right)\end{array}$} & \multicolumn{2}{|c|}{ 7days } & \multicolumn{2}{|c|}{ 28days } \\
\hline & & & & & & $\begin{array}{c}\text { Compressive } \\
\text { Strength } \\
(\mathrm{MPa}) \\
\end{array}$ & $\begin{array}{c}\text { Activity } \\
\text { Index } \\
(\%) \\
\end{array}$ & $\begin{array}{c}\text { Compressive } \\
\text { Strength } \\
(\mathrm{MPa}) \\
\end{array}$ & $\begin{array}{c}\text { Activity } \\
\text { Index } \\
(\%) \\
\end{array}$ \\
\hline O-SP-260 & $\mathrm{B} \times 1.9$ & $251 \times 250$ & 23.1 & 2.0 & 2.31 & 93.2 & & 116 & \\
\hline O-SP-230 & $\mathrm{B} \times 1.7$ & $225 \times 224$ & 22.0 & 1.3 & 2.33 & 93.9 & & 113 & \\
\hline O-SP-200 & $\mathrm{B} \times 1.6$ & $206 \times 206$ & 22.8 & 1.7 & 2.32 & 91.6 & & 112 & \\
\hline O-HSP-260 & $\mathrm{B} \times 0.9$ & $252 \times 249$ & 21.9 & 1.5 & 2.32 & 98.6 & & 117 & \\
\hline O-HSP-230 & $\mathrm{B} \times 0.8$ & $234 \times 233$ & 20.9 & 1.5 & 2.32 & 103 & & 122 & \\
\hline O-HSP-200 & $\mathrm{B} \times 0.73$ & $197 \times 195$ & 21.6 & 1.7 & 2.32 & 99.0 & & 120 & \\
\hline OSA-SP-260 & $\mathrm{B} \times 3.2$ & $254 \times 250$ & 22.3 & 1.7 & 2.29 & 95.7 & 103 & 127 & 109 \\
\hline OSA-SP-230 & $\mathrm{B} \times 2.4$ & $228 \times 227$ & 21.8 & 1.1 & 2.31 & 93.6 & 100 & 125 & 111 \\
\hline OSA-SP-200 & $\mathrm{B} \times 2.2$ & $210 \times 209$ & 19.9 & 1.1 & 2.31 & 96.8 & 106 & 129 & 115 \\
\hline OSA-HSP-260 & $\mathrm{B} \times 1.4$ & $260 \times 257$ & 20.9 & 0.7 & 2.32 & 98.9 & 100 & 134 & 115 \\
\hline OSA-HSP-230 & $\mathrm{B} \times 1.25$ & $235 \times 234$ & 21.3 & 1.2 & 2.30 & 102 & 99 & 133 & 109 \\
\hline OSA-HSP-200 & $\mathrm{B} \times 1.05$ & $207 \times 204$ & 21.3 & 1.3 & 2.30 & 96.6 & 98 & 130 & 108 \\
\hline OSB-SP-200 & $\mathrm{B} \times 4.0$ & $199 \times 197$ & 22.3 & 1.8 & 2.30 & 90.3 & 99 & 119 & 106 \\
\hline OSB-HSP-260 & $\mathrm{B} \times 2.0$ & $252 \times 255$ & 22.2 & 1.6 & 2.30 & 96.2 & 98 & 129 & 110 \\
\hline OSB-HSP-230 & $\mathrm{B} \times 1.8$ & $222 \times 222$ & 22.1 & 1.6 & 2.30 & 95.7 & 93 & 127 & 104 \\
\hline OSB-HSP-200 & $\mathrm{B} \times 1.6$ & $202 \times 200$ & 22.0 & 1.8 & 2.30 & 92.3 & 93 & 128 & 107 \\
\hline OV-SP-260 & $\mathrm{B} \times 1.7$ & $252 \times 248$ & 23.1 & 1.0 & 2.31 & 97.3 & 104 & 122 & 105 \\
\hline OV-SP-230 & $\mathrm{B} \times 1.5$ & $241 \times 239$ & 22.5 & 1.4 & 2.30 & 96.1 & 102 & 121 & 107 \\
\hline OV-SP-200 & $\mathrm{B} \times 1.3$ & $210 \times 206$ & 21.6 & 1.5 & 2.30 & 95.5 & 104 & 120 & 107 \\
\hline OV-HSP-260 & $\mathrm{B} \times 0.85$ & $259 \times 258$ & 20.8 & 1.5 & 2.30 & 97.8 & 99 & 127 & 109 \\
\hline OV-HSP-230 & $\mathrm{B} \times 0.78$ & $236 \times 235$ & 20.8 & 1.3 & 2.31 & 101 & 98 & 128 & 105 \\
\hline OV-HSP-200 & $\mathrm{B} \times 0.65$ & $194 \times 188$ & 20.8 & 1.6 & 2.30 & 101 & 102 & 125 & 104 \\
\hline
\end{tabular}

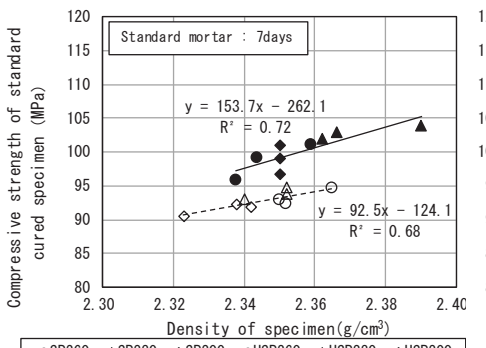

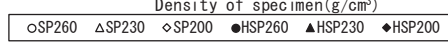

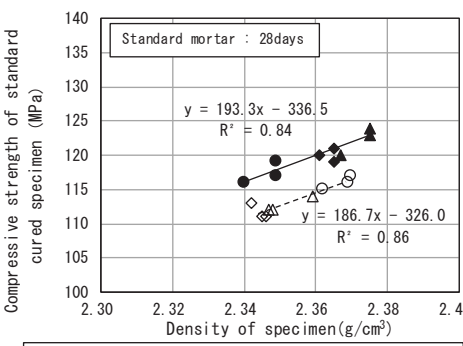

\begin{tabular}{|llllll}
\hline OSP260 & $\triangle S P 230$ & $\triangle S P 200$ & $\bullet H S P 260$ & $\Delta H S P 230$ & $\bullet H S P 200$
\end{tabular}
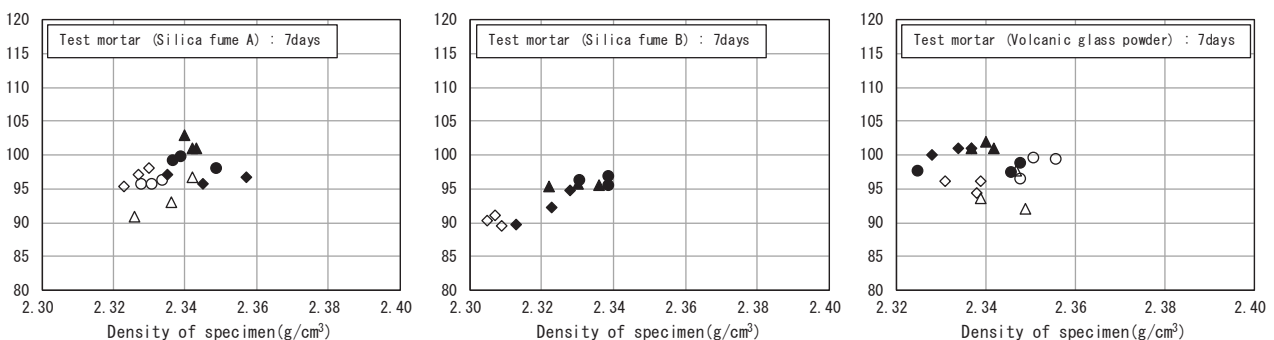

0 OSP260 $\triangle$ SP230 $\triangle$ SP200 $\bullet H S P 260 \triangle \mathrm{HSP} 230 \bullet \mathrm{HSP} 200$

(7days)
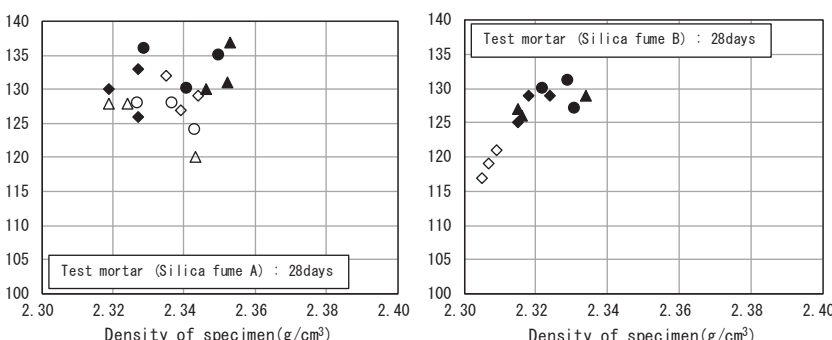

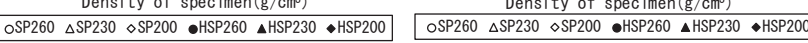

Density of $\operatorname{specimen}\left(\mathrm{g} / \mathrm{cm}^{3}\right)$

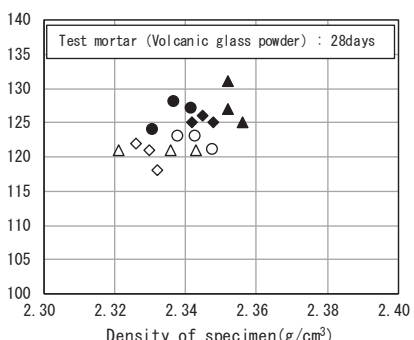

(28days)

Fig. 5 Relation between density of specimen and compressive strength

熱減量の值は高めではあるが, JIS の品質規格である $4.0 \%$ には収ま っている。したがって, 今回の結果は, JIS の規定通りの活性度指 数試験方法で規格に適合するシリカフュームを用いて試験を行って も，規定通りの試験モルタルが練り上がらないケースがあることを 示したことになる。
圧縮強度試験結果に関しては，いずれのフロー值とした場合も， ほぼ同様の結果となった。ただし，全体像としては，高性能減水剂 を用いたモルタルの圧縮強度が，高性能 $\mathrm{AE}$ 減水剤を使用したモル タルの圧縮強度よりも高くなる傾向にあった。その傾向は，特に基 準モルタルで顕著であるようにみえる。 
活性度指数試験の結果としては, 前述した圧縮強度試験のばらつ きが，活性度指数の值に反映しているようにみえる。特に，高性能 減水剂を用いた基準モルタルの圧縮強度が高くなったことは, 高性 能減水剤を用いた場合の活性度指数の值を相対的に小さくする結果 となっており, 化学混和剤の選定が試験結果に影響を与える可能性 を示唆していた。

供試体の密度と圧縮強度の関係を整理したものを Fig.5 に示す。 基準モルタルでは, フローの值にかかわらず, 供試体の密度と圧縮 強度の間には相関関係がある。また, 供試体の密度が同等であって も, 黒叙りでプロットした高性能減水剂を用いた場合の圧縮強度は, 白抜きでプロットした高性能 $\mathrm{AE}$ 減水剂を用いた場合の圧縮強度よ りも高くなる傾向にある。シリカフューム Aおよび B を用いた試験 モルタルでは, 全体的に左下から右上にプロットが並んでいるよう に見えるものもあるが, 基準モルタルに比べると, 供試体の密度と 圧縮強度の間の相関性などはあまり認められない。その傾向は火山 ガラス微粉末を用いた試験モルタルでも同様である。

以上の結果を整理すると, 今回の試験で比較したフローの範囲で あれば，再現性のあるモルタルの圧縮強度試験結果を得ることが可 能であり, 結果として活性度指数試験の結果の再現性も確保できる と考えれられた。市場にはシリカフューム B のような様々なシリカ フュームが存在するため, 目標とするフローの許容差はもう少し幅 があってもよいと考える。一方, 化学混和剤の種類を変更すること は, 活性度指数試験の結果の再現性に影響する可能性が高いことも 確認できた。現状では, 継続的に同じ超高強度コンクリート用微粉 末の活性度指数を評価し続ける場合などでは, 一連の試験で使用す る化学混和剤の種類を揃えるような対応が必要であると考える。

\section{5. 練混ぜ時間が活性度指数試験結果の再現性に及ぼす影響}

現行の JIS A 6207 の活性度指数試験方法では, モルタルの練混ぜ 量だけでなく, モルタルの練混ぜ時間も規定されている。仮に, 前 章 4.で明確となった基準モルタルの圧縮強度における化学混和剂 の種類の影響がモルタルの練混ぜ時間の不足に起因するものである とすれば, 練混ぜ時間の延長によって問題は解消寸る。そこで, 実 験の要因に練混ぜ時間を加えた試験を行うこととした。
使用材料は前章までの材料を踏襲するものとした。超高強度コン クリート用微粉末に関しては, 前章 4 . で使用したものと同じロッ トのシリカフュームA と火山ガラス微粉末を使用した。標準砂は前 章までの試験で使用したものと同じときに受け入れたものとした。 普通ポルトランドセメントおよび化学混和剤は, 前章までで使用し たものと同じ銘柄のロット違いのものを使用した。

実験の要因と水準を Table7 に示す。結合材の種類は, 基準モル タルとなる普通ポルトランドセメントのみとしたもの 1 種, 試験モ ルタルとなる普通ポルトランドセメントの $10 \%$ Table4 に示した シリカフューム Aおよび火山ガラス微粉末に置換したもの 2 種とし た。化学混和剤は, 高性能 $\mathrm{AE}$ 減水剤および超高強度コンクリート 用の高性能減水剤の 2 種とした。練混ぜ時間は, 表中の 1) で示し たJIS の規定通りの時間と，2）で示した JIS の規定時間よりも延 長した時間の 2 種とした。なお, 化学混和剤の使用量が実験結果に 影響することを避けるため, この実験では, JIS の規定通りの時間 で練り混ぜた基準モルタルのフローが $260 \pm 10 \mathrm{~mm}$ となる使用量を, 同じ化学混和剤を使用するすべての調合に適用した。前章と同様に, 消泡剤にはポリアルキレングリコール誘導体系消泡剂を使用し，化

Table7 Parameters

\begin{tabular}{|c|c|c|c|c|c|}
\hline Binders & $\begin{array}{c}\text { Chemical } \\
\text { admixtures }\end{array}$ & \multicolumn{4}{|c|}{ Mixing time } \\
\hline \multirow{8}{*}{$\begin{array}{l}\text { 1) } \mathrm{O}=100 \\
\text { 2) } \mathrm{O}: \mathrm{SA} \\
=90: 10 \\
\text { 3) } \mathrm{O}: \mathrm{V} \\
=90: 10\end{array}$} & \multirow{8}{*}{$\begin{array}{l}\text { 1) } \mathrm{SP} \\
\text { 2) } \mathrm{HSP}\end{array}$} & \multirow{4}{*}{ 1) $\mathrm{N}$} & (1) & $\begin{array}{l}\text { Cement \& sand } \\
\& \text { (test sample) }\end{array}$ & $30 \mathrm{~s}$ \\
\hline & & & (2) & $\begin{array}{l}\text { +Water } \\
\text { \& Chemical } \\
\text { admixture }\end{array}$ & $120 \mathrm{~s}$ \\
\hline & & & (3) & Stop & $20 \mathrm{~s}$ \\
\hline & & & (4) & Re-start & $160 \mathrm{~s}$ \\
\hline & & \multirow{4}{*}{ 2)L } & (1) & $\begin{array}{l}\text { Cement \& sand } \\
\& \text { (test sample) }\end{array}$ & $30 \mathrm{~s}$ \\
\hline & & & (2) & $\begin{array}{l}\text { +Water } \\
\text { \& Chemical } \\
\text { admixture }\end{array}$ & $240 \mathrm{~s}$ \\
\hline & & & (3) & Stop & $20 \mathrm{~s}$ \\
\hline & & & (4) & Re-start & $300 \mathrm{~s}$ \\
\hline \multicolumn{6}{|c|}{$\begin{array}{l}\text { O : Ordinary portland cement, SA : Silica fume A } \\
\text { SB : Silica fume B, V: Volcanic glass powder } \\
\text { SP : Air-entraining and high-range water-reducing admixture } \\
\text { HSP : high-range water-reducing admixture (for ultra-high strength } \\
\quad \text { concrete) }\end{array}$} \\
\hline
\end{tabular}

Table8 Activity index test results

\begin{tabular}{|c|c|c|c|c|c|c|c|c|c|}
\hline & \multirow{2}{*}{$\begin{array}{c}\text { Dosage of } \\
\text { chemical } \\
\text { Admixture } \\
(\%)\end{array}$} & \multirow[b]{2}{*}{$\begin{array}{l}\text { Flow } \\
(\mathrm{mm})\end{array}$} & \multirow[b]{2}{*}{$\begin{array}{c}\text { Temperature } \\
\left({ }^{\circ} \mathrm{C}\right)\end{array}$} & \multirow[b]{2}{*}{$\begin{array}{c}\text { Air } \\
\text { content } \\
(\%)\end{array}$} & \multirow{2}{*}{$\begin{array}{l}\text { Density } \\
\text { of flesh } \\
\text { mortar } \\
\left(\mathrm{g} / \mathrm{cm}^{3}\right) \\
\end{array}$} & \multicolumn{2}{|c|}{7 days } & \multicolumn{2}{|c|}{28 days } \\
\hline & & & & & & $\begin{array}{c}\text { Compressive } \\
\text { Strength } \\
(\mathrm{MPa}) \\
\end{array}$ & $\begin{array}{c}\text { Activity } \\
\text { Index } \\
(\%) \\
\end{array}$ & $\begin{array}{c}\text { Compressive } \\
\text { Strength } \\
(\mathrm{MPa}) \\
\end{array}$ & $\begin{array}{c}\text { Activity } \\
\text { Index } \\
(\%) \\
\end{array}$ \\
\hline $\mathrm{O}-\mathrm{SP}-\mathrm{N}$ & $\mathrm{B} \times 3.2$ & $265 \times 263$ & 22.8 & 1.2 & 2.33 & 89.8 & & 107 & \\
\hline O-SP-L & $\mathrm{B} \times 3.2$ & $259 \times 258$ & 23.3 & 1.3 & 2.33 & 93.4 & & 109 & \\
\hline $\mathrm{O}-\mathrm{HSP}-\mathrm{N}$ & $\mathrm{B} \times 0.9$ & $265 \times 263$ & 22.5 & 1.3 & 2.33 & 98.4 & & 114 & \\
\hline O-HSP-L & $\mathrm{B} \times 0.9$ & $260 \times 259$ & 21.5 & 2.2 & 2.31 & 99.7 & & 120 & \\
\hline OSA-SP-N & $\mathrm{B} \times 3.2$ & $211 \times 208$ & 21.8 & 1.3 & 2.30 & 92.4 & 103 & 127 & 119 \\
\hline OSA-SP-L & $\mathrm{B} \times 3.2$ & $229 \times 226$ & 20.7 & 1.4 & 2.30 & 94.4 & 101 & 128 & 117 \\
\hline OSA-HSP-N & $\mathrm{B} \times 0.9$ & $216 \times 214$ & 21.0 & 2.0 & 2.29 & 92.5 & 94 & 129 & 113 \\
\hline OSA-HSP-L & $\mathrm{B} \times 0.9$ & $226 \times 224$ & 20.5 & 1.9 & 2.29 & 97.4 & 98 & 131 & 109 \\
\hline OV-SP-N & $\mathrm{B} \times 3.2$ & $283 \times 282$ & 21.5 & 0.9 & 2.32 & 94.7 & 105 & 120 & 112 \\
\hline OV-SP-L & $\mathrm{B} \times 3.2$ & $307 \times 306$ & 20.9 & 1.0 & 2.31 & 97.2 & 104 & 124 & 114 \\
\hline OV-HSP-N & $\mathrm{B} \times 0.9$ & $308 \times 302$ & 21.3 & 2.1 & 2.29 & 96.8 & 98 & 126 & 111 \\
\hline OV-HSP-L & $\mathrm{B} \times 0.9$ & $307 \times 304$ & 20.8 & 1.5 & 2.30 & 103 & 103 & 130 & 108 \\
\hline
\end{tabular}



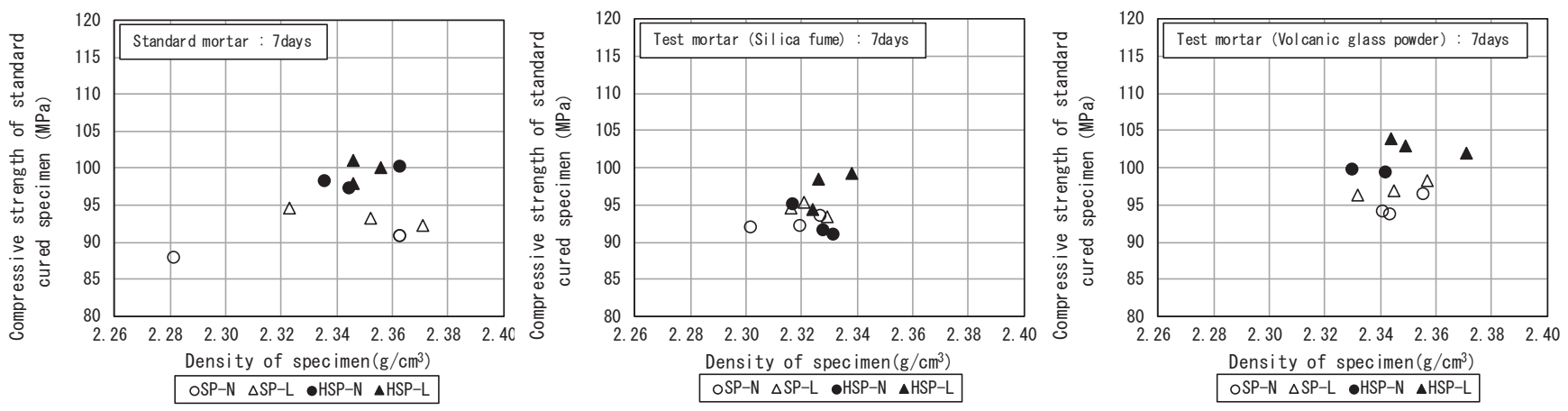

(7days)
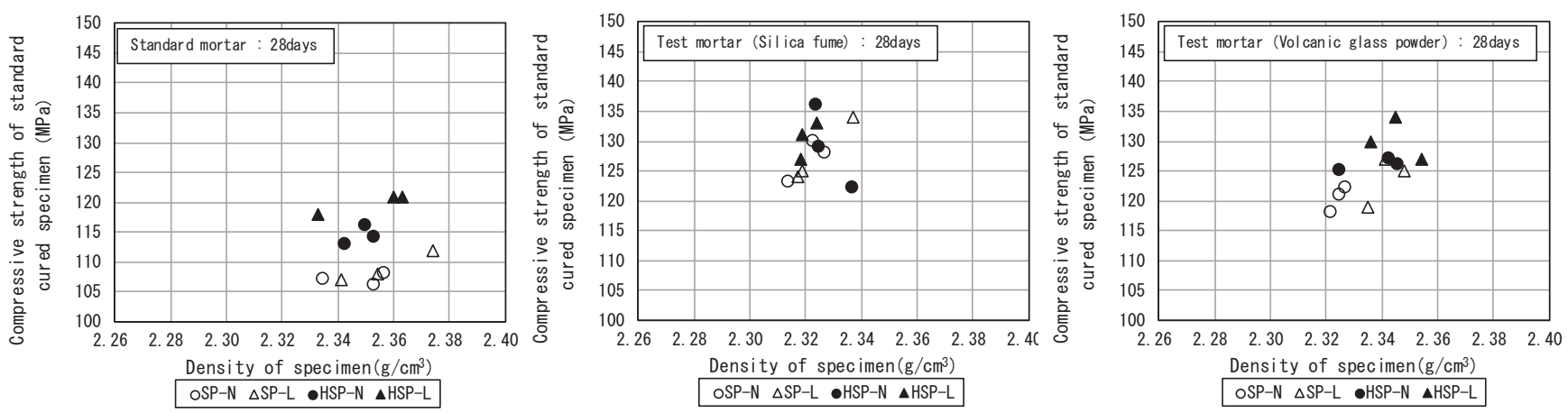

(28days)

Fig. 6 Relation between density of specimen and compressive strength

学混和剤の種類にかかわらず, 使用量は全バッチともセメント質量 の $0.3 \%$ とした。

モルタルの練混ぜは $20 \pm 3{ }^{\circ} \mathrm{C}$ の実験室で行った。実験開始時の実 験室内の湿度は $70 \%$ であった。フレッシュモルタルおよび硬化モル タルの試験結果を Table8 に示す。表に示した各モルタルの調合名 は, 次のルールで定めている。

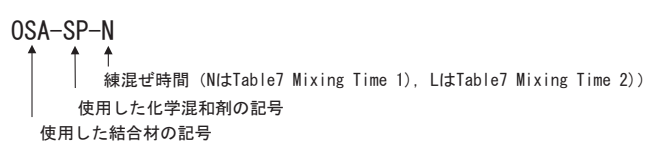

化学混和剂を同じ種類とした場合, 基準モルタルのフローの值は 練混ぜ時間を延長してもほとんど変わらなかった。空気量に関して は, 同等かやや増加する傾向であった。一方, 化学混和剂を同じ種 類とした場合，試験モルタルのフローの值はやや増加する傾向にあ った。空気量に関しては, 同等かやや減少寸る傾向であった。当初, 練混ぜ時間を延長することでモルタルのフローが増加し，モルタル 中の空気が抜けやすくなることを期待したが，そこまでの結果は得 ることができなかった。

圧縮強度は，一部を除き，ほぼ練混ぜ時間を延長したことで向上 した。当初, 基準モルタルでの高性能減水剤を用いたモルタルと高 性能 $\mathrm{AE}$ 減水剂を用いたモルタルの圧縮強度差が小さくなることを 期待していたが，練混ぜ時間の延長は高性能減水剤を用いたモル夕 ルでも強度増加に有効であったため, 想定した結果とはならなかっ た。そのため, 活性度指数試験の結果についても, 練混ぜ時間を延 長することで, 使用する化学混和剤の影響を抑制できるという結果 とはならなかった。
供試体の密度と圧縮強度の関係を整理したものを Fig.6 に示す。 前章までの結果と同様に，普通ポルトランドセメントのみを用いた 基準モルタルでは，練混ぜ時間にかかわらず，黒塗りでプロットし た高性能減水剂を用いたモルタルの圧縮強度が相対的に高くなる 傾向にあった。フレッシュモルタルでの結果と同様に，練混ぜ時間 を延長することで，供試体の密度が増加する（モルタル中の空気量 が減る）ような傾向は見られず, Table8 で得られた印象と変わらな かった。シリカフュームや火山ガラス微粉末を用いた試験モルタル でも, 練混ぜ時間の延長が強度増加以外のことに影響している傾向 は見られなかった。

以上の結果を整理すると，練混ぜ時間の延長は，各モルタルの圧 縮強度を向上させることには有効であったが，化学混和剤の種類の 違いが活性度指数試験の結果に及ぼす影響を抑制するような結果 にはならなかった。前述したように, 繰り返し同じ超高強度コンク リート用微粉末の活性度指数を評価し続ける場合などでは，使用す る化学混和剤の種類を揃えるような対応が必要であると考える。

\section{6. まとめ}

JIS A 6207 に規定される活性度指数試験方法の試験結果の再現 性に関する実験的な検証を行った。この結果，以下の知見を得た。

1）使用材料が同じであれば，現行の試験方法によって再現性のあ る基準モルタルの圧縮強度試験結果を得ることができる。

2)今回の試験で比較したフローの範囲 $(260,230 \mathrm{~mm}$ および $200 \mathrm{~mm})$ であれば，再現性のあるモルタルの圧縮強度試験結果を得るこ とが可能であり，このようなフローの範囲であれば，活性度指 
数試験結果の再現性も確保できると考えれられた。

3）化学混和剂の種類の変更は, 活性度指数試験の結果の再現性に 影響する可能性が高かった。

4）練混ぜ時間の延長は，基準モルタルと試験モルタルの圧縮強度 を向上させる結果になった。しかし，この結果によって 3）の問 題を抑制できるわけではなかった。

\section{謝辞}

本研究の一部は、工業標準化推進事業委託費戦略的国際標準化加 速事業: 産業基盤分野に係る国際標準開発活動新市場創造型 JIS の 開発「コンクリート用火山ガラス微粉末の開発」の一環として行っ たものです。試験にあたっては, 長瀧重義東京工業大学名誉教授, 故友澤史紀東京大学名誉教授, 坂井悦郎東京工業大学名誉教授, 野 口貴文東京大学教授, 佐伯竜彦新潟大学教授, 友寄篤東京大学助教 にご助言を頂きました。使用材料の提供に関しては，太平洋セメン 卜, 宇部三菱セメント, 住友大阪セメント, 巴工業, 鹿児島県工業 技術センター，プリンシプル， BASF ジャパンの協力を得ました。 実験に関しては, 平成 30 年度および令和元年度東京工芸大学建築 材料研究室卒研生の協力を得ました。記して謝意を表します。

\section{参考文献}

1)Ishikawa, Y. : A basic study on activity index in Japanese industrial standard of fly ash for use in concrete, AIJ Journal of Technology and Design, Vol.18, No.40, pp.819-822, 2012.10 (in Japanese)
石川嘉崇：コンクリート用フライアッシュの JIS における活性度指数に関 する一考察，日本建築学会技術報告集, Vol.18, No.40, pp.819-822, 2012.10 2)Architectural Institute of Japan : Guideline for mix proportion and construction of concrete using silica fume,1996.1 (in Japanese) 日本建築学会：シリカフュームを用いたコンクリートの調合設計・施工ガ イドライン,1996.1

3)Japan Society of Civil Engineers : (Guideline for design and construction of concrete using silica fume), 1995.10 (in Japanese)

土木学会：シリカフュームを用いたコンクリートの設計・施工指針 (案) , 1995.10

4)Watanabe, S., Hori, A., Naruse, H. and Nagataki, S. : Study on influences of quality of silica fume on quality of high strength concrete, Cement science and concrete technology,No.62,pp.419-426, 2008(in Japanese)

渡邊悟士, 保利彰宏, 鳴瀬浩康, 長瀧重義 : シリカフュームが高強度コン クリートの物性に及ぼす影響の評価に関する研究，セメント・コンクリー 卜論文集, No.62,pp.419-426, 2008

5)JIS A 6209 (Volcanic glass powder for use in concrete), pp.7-8, 2020.3(in Japanese)

JIS A 6209 (コンクリート用火山ガラス微粉末), pp.7-8, 2020.3

6)Jinnai, H., Tomoyose, A. and Noguchi, T. : (Fundamental study on test method for activity index of volcanic glass powder based on mortar), Proceedings of the $46^{\text {th }}$ JUCC Congress on cement and concrete, 35-38,2019.11(in Japanese)

陣内 浩, 友寄 篤, 野口貴文：火山ガラス微粉末の活性度指数試験に関 する基礎的研究，第 46 回セメント・コンクリート研究討論会論文報告集， 35-38,2019.11

7)Architectural Institute of Japan : Recommendation for practice of high-strength concrete, p.212, 2005.1

日本建築学会：高強度コンクリート施工指針(案),p.212, 2005.1 


\section{CONSIDERATION IN REPEATABILITY OF ACTIVITY INDEX TEST RESULTS \\ OF MICRO POWDER FOR ULTRA-HIGH STRENGTH CONCRETE BASED ON MORTAR}

\section{Hiroshi JINNAI ${ }^{* 1}$}

\footnotetext{
${ }^{* 1}$ Prof., Dept. of Architecture, Faculty of Engineering, Tokyo Polytechnic University, Ph.D.
}

An activity index test of mineral admixture for concrete is the test of estimates the substitution performance of the mineral admixture to cement. This test is prescribed by JIS A 6201 (Fly ash for use in concrete), JIS A 6206(Ground granulated blast-furnace slag for use in concrete) and JIS A 6207 (Silica fume for use in concrete).

Mortar with water binder ratio of 50\% prescribed in JIS A 6201 isn't suitable to estimate the activity index of the silica fume. This is because silica fume is used by ultra-high strength concrete with low water binder ratio. The water binder ratio of the mortar used for a test after JIS A 6207(2011) was changed to 30\% from this reason. About 10 years had passed from this change, but a problem related to a revised point wasn't reported. However, a problem about the repeatability of the activity index test results was pointed out by an experiment related to establishment of JIS A 6209(Volcanic glass powder for use in concrete). Then, repeatability of activity index test results of micro-powder for ultra-high strength concrete based on mortar was investigated. This investigation led to the following conclusions.

1) It is possible to obtain a compressive strength test result of the standard mortar with repeatability by a present test method when used material is same.

2) In the range of a mortar flow of this test $(200 \mathrm{~mm}-260 \mathrm{~mm})$, it is possible to obtain a compressive strength test result of the standard mortar with repeatability. As a result, the repeatability of a result of the activity index test can also be secured.

3) To change the kind of chemical admixture has a high possibility which influences the repeatability of a result of the activity index test.

4) Extension of mixing time contributed to increase compressive strength of standard mortar and test mortar. However, a problem of 3) could not be solved by extending mixing time of mortar. 